\title{
Anti-Inflammatory and Central Analgesic Effect of the Aqueous Extract of the Leaves of Vitex Madiensis Oliv (Lamiaceae-Viticoïdeae)
}

Nsonde Ntandou $\mathrm{GF}^{1,2^{*}}$, Dianzitoukoulou Matsima L.D. ${ }^{2}$, Ingabire $\mathrm{J}^{2}$, Makemba Nkounkou $\mathrm{GS}^{2}$, Nkundineza $\mathrm{JC}^{2}$, ABENA AA ${ }^{1}$

${ }^{1}$ Laboratoire de biochimie et pharmacologie, Faculté des Sciences de la Santé, Université Marien Ngouabi, BP 69, Brazzaville, Congo

${ }^{2}$ Laboratoire de Physiologie et Physiopathologie Animales, Faculté des Sciences et Techniques, Université Marien NGOUABI, Brazzaville, BP 69, Congo

DOI: $10.36348 /$ sijtcm.2020.v03i01.002

| Received: 03.01.2020 | Accepted: 10.01.2020 | Published: 27.01.2020

*Corresponding author: Nsonde Ntandou GF

\section{Abstract}

Vitex madiensis Oliv is a plant of the family of the Lamaceae-Viticoideae used in traditional medecine in Congo against: dysenteriform diarrheas, barreness of the women, madness, otitis, tooth decay, oral affections, malaria, inflammation of ganglia and stiffness. The aqueous extract of leaves of Vitex madiensis oliv. was the subject of an investigating by the carraghenine and the histamine induced inflammation, and on the central pain of thermal origin at the doses of 50, 100, 200 and $400 \mathrm{mg} / \mathrm{kg}$ per os. A significant anti-inflammatory effect $(* * * \mathrm{p}<0,001)$ at the dose of $400 \mathrm{mg} / \mathrm{kg}$ from the thirst hour and at the dose of $200 \mathrm{mg} / \mathrm{kg}$ from 3hours was observed. A significant (***p<0,001) analgesic effect was observed at the dose of $400 \mathrm{mg} / \mathrm{kg}$ from 30 minutes. These effects are due to the presence of the numerous metabolites contained in this extract.

Keywords: Vitex madiensis, aqueous extract, anti-inflammatory, analgesic.

Copyright @ 2020: This is an open-access article distributed under the terms of the Creative Commons Attribution license which permits unrestricted use, distribution, and reproduction in any medium for non-commercial use (NonCommercial, or CC-BY-NC) provided the original author and source are credited.

\section{INTRODUCTION}

In Congo, the traditional medicine is a nonnegligible remedy for the population. Also, to improve its performance, the Congolese government has launched a promotion strategy aimed at integrating it into the health system through the development of medicinal plants [1]. This strategy is motivated on the one hand by the richness of the culture and the traditions on the use of the medicinal plants and on the other hand by the richness and the diversity of the flora.

Indeed, the flora of the Republic of Congo includes many medicinal plants with therapeutic properties, which can remedy multiple pathological disorders including those related to inflammation $[2,13$, $4,5-8]$. It is in this context that we wanted to contribute to the development of plants with anti-inflammatory and analgesic effects used in traditional Congolese medicine to fight against pain and inflammation. The genus vitex is reported to be rich in medicinal virtues; it is used as food, for the treatment of post-delivery bleeding, treatment of premenstrual and gynecologic affections, sexual enhancer, to control the foul odor of external genitalia, gastrointestinal disorders, as anthelmintic, astringent, stomachic, bacterial infections, pain, inflammation, diarrhea, fever, as a tonic, cramps, malaria, convulsion, insect repellent, against stings of venomous animals and in wound healing [9-12].

Aqueous extract of $V$. glabrata is reported to have Human Immunodeficiency Virus-1 (HIV-1) reverse transcriptase inhibitory activity. Vitex agnuscastus L has been used to treat pain, swelling, inflammation, headaches, rheumatism, and sexual dysfunction [13]. Vitex mollis, Vitex piramidata, Vitex pubescens, Vitex agnuscastus and Vitex gaumeri are reported to possess antidysentery, analgesic, antiinflammatory, anti-tumor activities [12].

Vitex madiensis is used in the Congo to treat dysenteryforme diarrhea, female sterility, insanity, ear infections, fever, pain, dental caries, oral diseases, malaria, inflammation of the ganglions and body aches $[14,15]$. Thus, in order to provide a scientific basis for the use of Vitex mandiesis Oliv. Against pain and inflammation in traditional medicine, this study aims to evaluate anti-inflammatory and analgesic effects of the aqueous extract of leaves of Vitex madiensis Oliv on the pain of central type. 


\section{MATERIAL AND METHODS \\ Plant material}

The assessed plant material consists mainly of Vitex madiensis Oliv leaves collected at Makana village (pool department), in April 2017. Plant species was identified in the Congo National Herbarium by botanists from the Botany Laboratory of the Institut National de Recherche en Sciences Exactes et Naturelles (IRSEN) of Brazzaville-Congo. The sample was dried at room temperature in the Laboratoire de Physiologie et Physiopathologie Animales of Faculté des Sciences et Techniques of Université Marien NGOUABI of Brazzaville-Congo. The dry leaves were pulverized and the resulting powder was used to prepare the extract.

\section{Animal material}

The treated animals are male and female, Wistar rats weighing between 175 and $200 \mathrm{~g}$, and mice weighing between 18 and $20 \mathrm{~g}$, raised at the Faculté des Sciences et Techniques (FST) animaleria under standard conditions $\left(25 \pm 5^{\circ} \mathrm{C}, 40-70 \mathrm{RH}\right)$, with a diurnal cycle of 12 hours of light and 12 hours of darkness. These rats had free access to water and a standard food. The ethical rules of animal experiments published by the International Association for the Study of Pain was respected [16, 17].

\section{METHODS}

\section{Preparation of extracts}

The aqueous extract was prepared by the decoction method. $50 \mathrm{~g}$ of Vitex madiensis leaves powder were placed in $500 \mathrm{~mL}$ of distilled water and boiling at $100^{\circ} \mathrm{C}$ during 30 minutes, then filtered with cotton, concentrated at reduced pressure at 50-60 ${ }^{\circ} \mathrm{C}$ and kept at $4^{\circ} \mathrm{C}$. The dry extract obtained was used to prepare the various test solutions.

\section{Anti-inflammatory activity}

In order to evaluate the anti-inflammatory effect of the aqueous extract of Vitex madiensis leaves, a model of acute inflammation was produced in vivo in male rats weighing between 100 and $250 \mathrm{~g}$, using the carrageenan and histamine. Animals are deprived of food (but no water) for 18 hours before the test.

\section{Acute inflammation induced by the carrageenan}

The injection of $0.05 \mathrm{ml}$ of $1 \%$ carrageenan into the plantar region of the right hind paw of the rat induced edema 30 minutes later, acute inflammation is observed by increased the diameter of paw [18]. This edema can be reduced by treatment with antiinflammatory substance.

Thirty (30) rats were selected and divided into six (6) groups of five (5) rats:

- group1 (control): treated with distilled water $10 \mathrm{~mL} /$ $\mathrm{kg} / \mathrm{rat}$ per os;

- group 2 (reference): treated with diclofenac $(50 \mathrm{mg})$ at a dose of $5 \mathrm{mg} / \mathrm{kg} / \mathrm{rat}$ per os;
- group 3, 4, 5, 6 (test groups): treated with 50, 100, 200 and $400 \mathrm{mg} / \mathrm{kg} / \mathrm{rat}$ per os of the aqueous extract of Vitex mandiensis Oliv. An initial measurement $(\mathrm{d} 0)$ of the paw is taken in each animal before induction of edema.

One (1) hour after the oral administration of the different substances, $0.05 \mathrm{ml}$ of a fresh carragenine suspension $(1 \%$ carrageenin in $0.9 \% \mathrm{NaCl})$ was injected to all animals subcutaneously at the fascia of the right hind paw (PPD).

After the injection of the oedematogenic agent, the evolution of the edema is controlled by measuring the diameter $(\mathrm{dt})$ of the PPD at $1 / 2 \mathrm{~h}, 1 \mathrm{~h}, 2 \mathrm{~h}, 3 \mathrm{~h}, 4 \mathrm{~h}$ and $24 \mathrm{~h}$ using a caliper. The percentages of inhibition of the edema (PINH) are calculated according to the following formula:

\section{PINH=M (dt-d0)}

$\mathrm{dt}$ : diameter of the paw after induction of inflammation at time $\mathrm{t}$;

d0: diameter of the paw before induction of inflammation;

M: average.

\section{Acute inflammation induced by the histamine [24]}

Indeed, histamine is a polysaccharide that injected into an animal, causes 30 minutes after acute inflammation during which the volume of the paw increases with time. An anti-inflammatory substance inhibits this increase compared to the control that received distilled water. The induction of inflammatory edema on the rat's paw with histamine was carried out as follows:

Twenty (20) animals were selected, divided into four (4) groups of 5 rats and treated as follows:

- $\quad$ groupe 1 (control): treated with distilled water 10 $\mathrm{mL} / \mathrm{kg} / \mathrm{rat}$ per.os;

- $\quad$ groupe 2 (reference): treated with diclofenac at a dose of $5 \mathrm{mg} / \mathrm{kg} / \mathrm{rat}$ per os;

- groupe 3 (test group): treated with the aqueous extract of Vitex mandiensis Oliv at $400 \mathrm{mg} / \mathrm{kg} / \mathrm{rat}$ per os;

- groupe 3 (test group): treated with the aqueous extract of Vitex mandiensis Oliv at $200 \mathrm{mg} / \mathrm{kg} / \mathrm{rat}$ per os;

An initial measurement (d0) of the paw is taken in each animal before the induction of edema.

One (1) hour after the oral administration of the various substances, $0.05 \mathrm{ml}$ of a fresh suspension of histamine was injected into all the animals by subcutaneous route at the level of the fascia of the right hind paw (PPD). 
After the injection of the edematogenic agent, the development of the edema is monitored by measuring the diameter $(\mathrm{dt})$ of the (PPD) at $1 / 2 \mathrm{~h}, 1 \mathrm{~h}$, $2 \mathrm{~h}, 3 \mathrm{~h}, 4 \mathrm{~h}$ and $24 \mathrm{~h}$ using a caliper.

\section{Analgesic activity: tail immersion test in hot water}

We modified the method firstly described by D'Amour \& Smith [20]. This test involves to induce pain by immersing the tail of the animal in a bath of hot water at a temperature of $57 \pm 2{ }^{\circ} \mathrm{C}$. The animals are previously treated orally by different test products, 30 minutes after the administration of the products, they were kept in a vertical position to immerse its tail with a depth of $5 \mathrm{~cm}$ in hot water maintained at $57 \pm 2^{\circ} \mathrm{C}$. The reaction time (in seconds) that the animal takes to remove its tail from water was noted $30,60,90$ and 120 minutes after administration of product. The maximum time that the animal must pass in hot water during this test is 30 seconds. Exceed this time the animal is not taken into account. The pain sensation is characterized by the rapid withdrawal of the tail of the animal. An analgesic would act by increasing the reaction time of the animal. Five (5) lots of five (5) mice each were made. The mice were treated as follows:

- the $1^{\text {st }}$ group (control) received $10 \mathrm{~mL} / \mathrm{kg}$ of distilled water per mouse;

- the $2^{\text {nd }}$ group received $100 \mathrm{mg} / \mathrm{kg}$ of tramadol, used as reference molecule per mouse;
- the $3^{\text {rd }}$ group received $200 \mathrm{mg} / \mathrm{kg}$ of the aqueous extract of the roots of Naucl latifolia leaves per mouse;

- the $4^{\text {th }}$ group received $400 \mathrm{mg} / \mathrm{kg}$ of the aqueous root extract of Nauclea latifolia leaves per mouse;

- $\quad$ the $5^{\text {th }}$ group received $800 \mathrm{mg} / \mathrm{kg}$ of aqueous extract of Nauclea latifolia leaves per mouse;

\section{STATISTICAL ANALYSIS}

The results we obtained, are expressed as an average \pm ES for a number of 5 animals per group using the Microsoft Excel Windows 13 software. The results obtained in the test groups were compared to the negative control group using the $\mathrm{t}$ test. Student and significance was established with probabilities $* \mathrm{p}<0.5$; $* * \mathrm{p}<0.01$ and $* * * \mathrm{p}<0.001$.

\section{RESULTS}

\section{Anti-inflammatory effect}

\section{Inflammation induced by the carrageenan}

The aqueous extract of Vitex madiensis showed a very significant anti-inflammatory effect at the dose of $400 \mathrm{mg} / \mathrm{kg}$ per os observable from 1 hour until the end of the experiment after 24 hours (Figure $1)$.

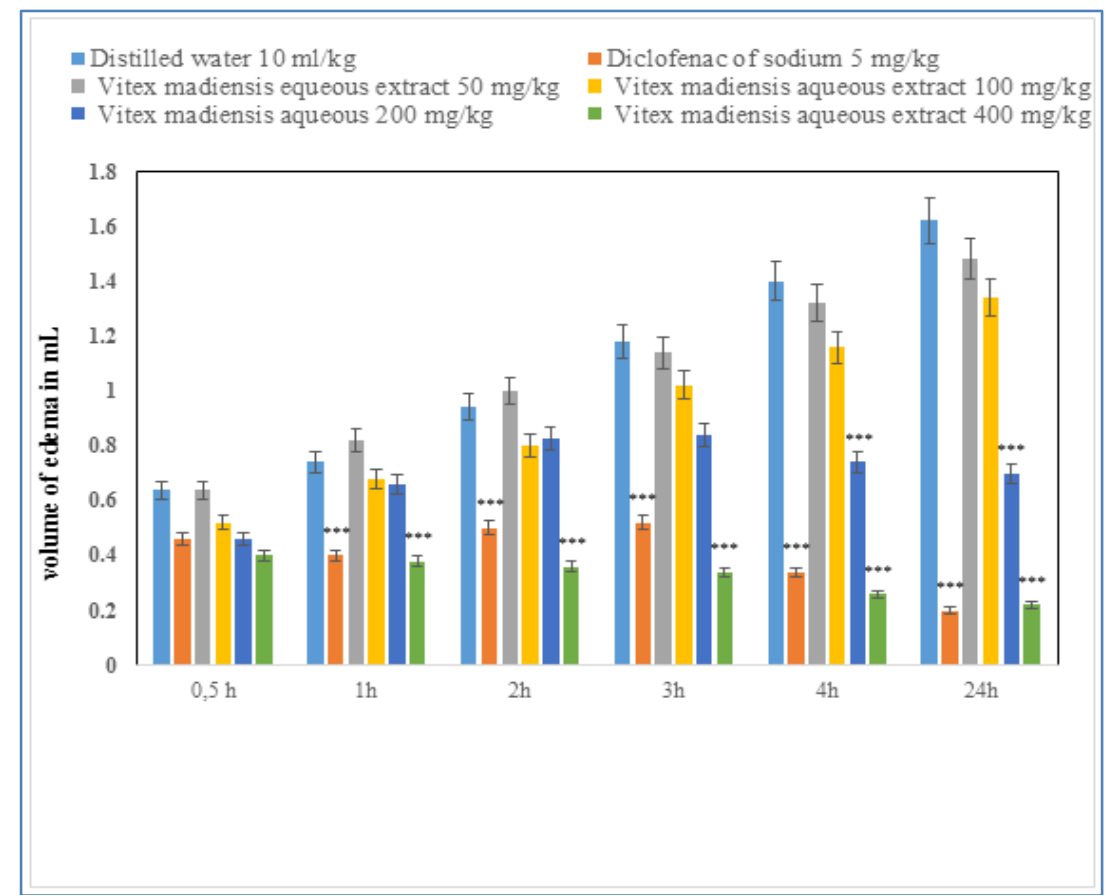

Fig-1: Vitex madiensis aqueous extract antiinflammatory activity on carrageenan-induced rat paw edema,results expressed by mean \pm SE, $* * * P<0.001, n=5$

\section{Inflammation induced by histamine}

The aqueous extract of Vitex madiensis has an antinflammatory effect at $400 \mathrm{mg} / \mathrm{kg}$ per os very significant $(* * * \mathrm{p}<0.001)$ on the histamine-induced inflammation observed after $2 \mathrm{~h}$ (Figure 3). 


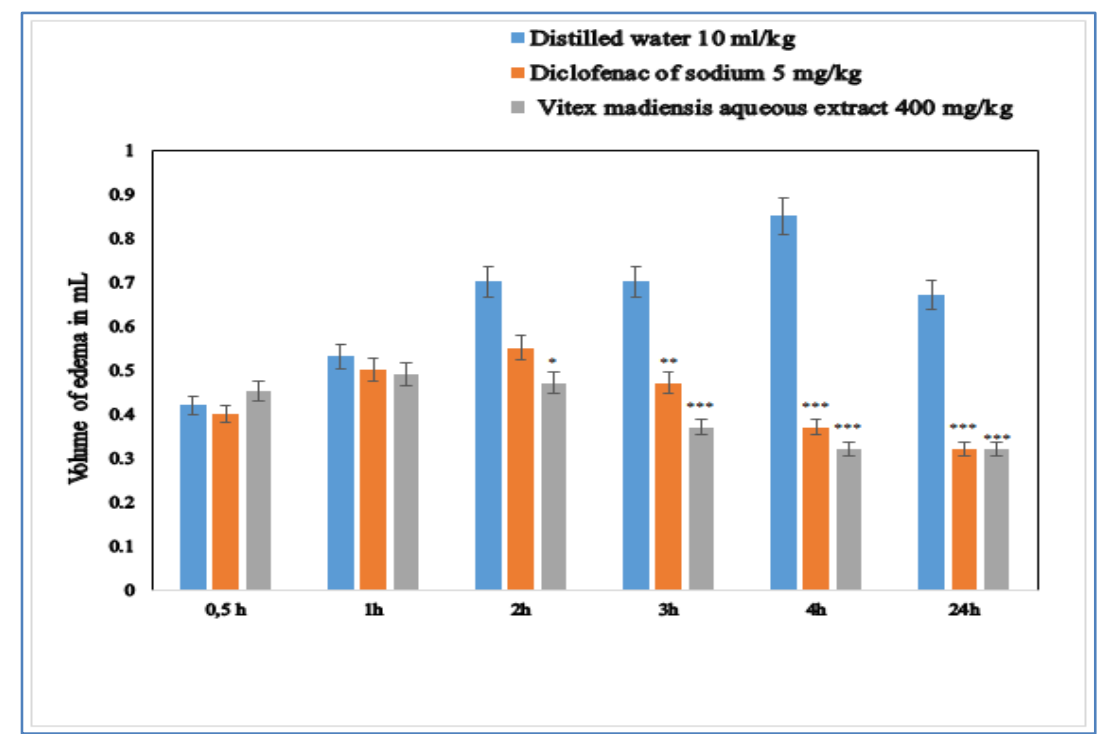

Fig-2: Vitex madiensis aqueous extract antiinflammatory activity on histamine-induced rat paw edema,results expressed by mean \pm SE, ${ }^{* P}<$ $0.5, * * * P<0.001, n=5$

\section{Analgesic effect}

The aqueous extract of Vitex madiensis showed a very significant central type analgesic effect
$(* * * \mathrm{p}<0.001)$ at a dose of $400 \mathrm{mg} / \mathrm{kg}$ per os remarkable after $0.5 \mathrm{~h}$ up to $2 \mathrm{~h}$ (Figure 3 ).

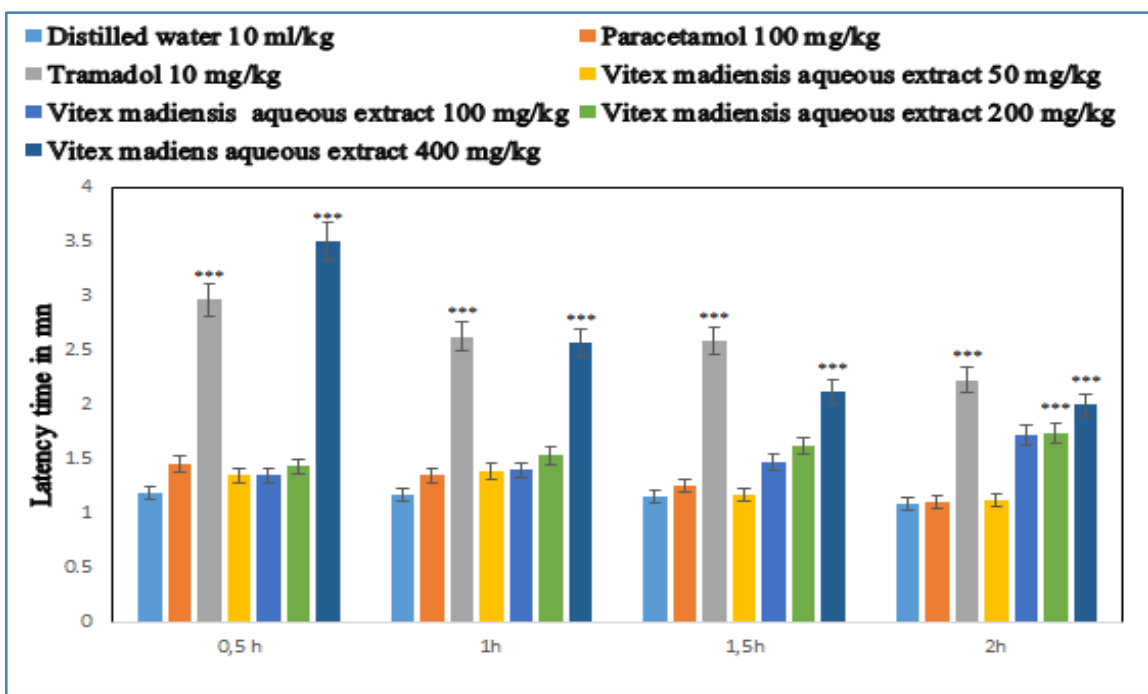

Fig-3: Analgesic activity of Vitex madiensis aqueous extract on tail flick method, results expressed by mean $\pm \mathrm{SE}, * * * \mathrm{P}<0.001, \mathbf{n}=5$

\section{DISCUSSION}

The purpose of this work was to evaluate the anti-inflammatory and analgesic effect of Vitex madiensis Oliv leaves aqueous extract on the pain of central type. An earlier study by Ngoka et al. [15] has demonstrated an analgesic effect on the pain of peripheral type. On this work we have demonstrated the anti-inflammatory activity and confirmed the analgesic activity on the pain of central type.

Carrageenan is a polysaccharide that induces local inflammation characterized by increased vascular permeability, edema and extravasation of neutrophils. Its action is done in two: the first phase (1/2 to 1 hour) involves the release of amino-vasoactive mediators (histamine, serotonin) and the second phase (1 hour later) is mediated by prostaglandins. Carrageenin edema is an excellent, reliable model of acute inflammation [21-23]. The thermal test is well recognized for the evaluation of an analgesic activity having a central mechanism of action. The result obtained shows a very significant anti-inflammatory effect at a dose of $400 \mathrm{mg}$ $/ \mathrm{kg}$. This extract inhibits the evolution of edema until the last phase of carrageenan-induced inflammation. This result is in agreement with those found by Iwueke et al. [24] which showed an anti-inflammatory effect of Vitex doniania which is of the same genus with Vitex madiensis. This effect could be explained by the inhibition of prostaglandin release and / or the reduction of their effect, as already demonstrated with Vitex doniania Sweet and Vitex negundo Linn [25, 24, 26, 27]. 
However, it should be noted that the antiinflammatory effect induced by histamine is observed after about 1 hour 30 minutes of the edema induced by carrageenin (30 min). It may be thought that our extract does not block the action of histamine. The antiinflammatory effect would therefore be mediated via inhibition of cyclooxygenase as it was already been demonstrated with other species of the genus vitex or with other botanical families [24, 4, 15, 27]. PGs are formed due to arachidonic acid metabolism catalyzed by the cyclooxygenase (COX) enzymes in cells $[28,29$, $25,30]$.

An analgesic effect of central type has been highlighted. Unlike the active doses (50, 100 and 200 $\mathrm{mg} / \mathrm{kg}$ ) used by N'goka et al. [15], here the activity is remarkable at $400 \mathrm{mg} / \mathrm{kg}$. Three (3) hypotheses can be evoked to explain this difference: the first one is not the same physiopathological mechanism of pain induction, therefore is not the same mechanism of action of the "drug"; second it is not maybe the same active principles involved in the two types of actions; and the third is that the concentration of the active ingredient in the extract would be different either for reasons of samples that would have undergone an ecological or climatic influence or for reasons of manipulation during the preparation of the extract. Nevertheless, this result is in agreement with those of our predecessors who also demonstrated a central type analgesic effect using the hotplate test and the paw pressure test [24, 27]. These effects would be due to the presence of the secondary metabolites present in this extract [15].

\section{CONCLUSION}

The aqueous extract of Vitex madiensis has an anti-inflammatory effect and analgesic effect on central type of pain at 200 and $400 \mathrm{mg} / \mathrm{kg}$ per os in the rat.

\section{ACKNOWLEDGMENTS}

The authors are grateful botanists from the Botany Laboratory of the Institut National de Recherche en Sciences Exactes et Naturelles (IRSEN) of Brazzaville-Congo for botanical identification of plant. We are also grateful traditional healers for availing their facilities and time for some aspects of this study.

\section{REFERENCES}

1. World Health Organization. (2014). Resolutions and decisions of regional interest adopted by the Sixty-seventh World Health Assembly and the Executive Board at its 134th and 135th Sessions (No. EM/RC61/8 Rev. 1). World Health Organization. Regional Office for the Eastern Mediterranean.

2. Itou, R. D. G. E., Sanogo, R., Ossibi, A. W. E., Ntandou, F. G. N., Ondelé, R., Pénemé, B. M., ... \& Abena, A. A. (2014). Anti-inflammatory and analgesic effects of aqueous extract of stem bark of
Ceiba pentandra Gaertn. Pharmacology \& Pharmacy, 5(12), 1113.

3. Nkounkou, G. S. M., Ntandou, G. F. N., Peneme, B. M. L., Massengo, A. B., Ouamba, J. M., \& Abena, A. A. (2017). Enquête ethnobotanique et effets de l'extrait aqueux des rhizomes de Anchomanes difformis Blume. Engl (Araceae) sur la motricité utérine de cobaye. Pharmacopée et médecine traditionnelle africaine, 18(2), 13-20.

4. Ntandou, G. N., Banzouzi, J. T., Mbatchi, B., Elion-Itou, R. D. G., Etou-Ossibi, A. W., Ramos, S., ... \& Ouamba, J. M. (2010). Analgesic and antiinflammatory effects of Cassia siamea Lam. stem bark extracts. Journal of ethnopharmacology, 127(1), 108-111.

5. GF, N. N., Bassoueka, D. J., Banzouzi, J. T., AW, E. O., RDG, E. I., Makambila, M. C., ... \& Ouamba, J. M. (2015). Assessment of Cassia siamea stem bark extracts toxicity and stability in time of aqueous extract analgesic activity. African Journal of Pharmacy and Pharmacology,9(41), 988-994.

6. Nsonde Ntandou, G. F. (2017). Central Mechanism of Analgesic Effect of The Aqueous Extracts of Schwenckia Americana and Lupeol Its Main Isolated Active Molecule. SF Pharma J, 1 .

7. Nsonde Ntandou G.F., Boumba L.S., Gouollaly T., Makambila M.C., Ouamba J.M., Abena A.A.(2017). Acute toxicity, anti-inflammatory and analgesic effects of aqueous extract of Tetracera alnifolia Willd. (Dilleniaceae). Research Journal of Pharmacology and Pharmacy, 1(2):1-10.

8. Nsonde, Ntandou, G.F., Makambila, M.C., Banzouzi, J.T., Ouamba, J.M., Abena A.A.(2017). Pharmacological Investigation of Schwenckia americana L. on Pain, Behavior and Inflammation in Rodents. Galore International Journal of Health Sciences and Research, 2(4):33-44.

9. Chouhan, H. S., Sridevi, K., Singh, N. K., \& Singh, S. K. (2012). Anti-inflammatory activity of ethanol extract of Vitex glabrata leaves. Pak. J. Pharm. Sci, 25(1), 131-134.

10. Luecha, P., Umehara, K., Miyase, T., \& Noguchi, H. (2009). Antiestrogenic constituents of the Thai medicinal plants Capparis flavicans and Vitex glabrata. Journal of natural products, 72(11), 1954-1959.

11. Niare, A. (2011). Etude phytochimique et des activités biologiques de Evolvulus alsinoides L (Convolvulaceae) et de Vitex simplicifolia Oliv.(Verbenaceae) utilisées dans la prise en charge du paludisme en médecine traditionnelle.

12. Moke, L. E., Koto-te-Nyiwa Ngbolua, G. N., Bongo, L., Messi, M., Noté, O. P., Mbing, J. N., ... \& Mpiana, P. T. (2018). Vitex madiensis Oliv.(Lamiaceae): phytochemistry, pharmacology and future directions, a mini-review. Journal of Pharmacognosy and Phytochemistry, 7(2), 244251. 
13. Habbab, A., Sekkoum, K., Belboukhari, N., Cheriti, A., \& Y Aboul-Enein, H. (2017). Analgesic and Anti-Inflammatory Effects of Essential Oils of Vitex agnuscastus L. from SouthWest of Algeria. Current Bioactive Compounds, 13(2), 165-169.

14. Koster, R., Anderson, M., de Beer, E. J., Okolo, C. O., Johnson, P. B., Abdurahman, E. M., ... \& Ogunti, O. O. (1959). Feticheurs et Medecine Traditionnelles du Congo Brazzaville. Pakistan Journal of Biological Sciences, 7(9), 412-412.

15. Nsonde Ntandou, G. F., Boumba, S. L., \& Abena, A. A. (2018). Chemical Screening, Acute Toxicity and Analgesic Effect of the Aqueous Extracts of Vitex madiensis Oliv.(Lamiaceae-Vitico $\tilde{A}^{-}$deae) and Phytolacca dodecandra Lâ€TM HÃC rit.(Phytolaccaceae) Leaves. International Journal of Sciences, 7(01), 1-9.

16. Canadian council on Animal care, 1980. Guide to the Care use of experimental animals. Vol 1, appendix IV, 85p.

17. Zimmermann, M. (1983). Ethical guidelines for investigations of experimental pain in conscious animals. Pain, 16(2), 109-110.

18. Borgi, W., Ghedira, K., \& Chouchane, N. (2007). Antiinflammatory and analgesic activities of Zizyphus lotus root barks. Fitoterapia, 78(1), 1619.

19. Cezmi, A., Akdis M.D., \& Kurt Blaser, P. (2003). Histamine in the immune regulate of alergic inflammation from the swiss. Journal of Allergy clinical Immunology; volume 112, 1: 15-22.

20. D'amour, F.E., \& Smith D.L., (1941). Journal of Pharmacology and Experimental. Therapeutics, 72(1) 74-79.

21. Averbeck, B., \& Reeh, P. W. (2001). Interactions of inflammatory mediators stimulating release of calcitonin gene-related peptide, substance $\mathrm{P}$ and prostaglandin E2 from isolated rat skin. Neuropharmacology, 40(3), 416-423.

22. Barton, G. M. (2008). A calculated response: control of inflammation by the innate immune system. The Journal of clinical investigation, 118(2), 413-420.

23. Ammon, H. P. T., Safayhi, H., Mack, T., \& Sabieraj, J. (1993). Mechanism of antiinflammatory actions of curcumine and boswellic acids. Journal of ethnopharmacology, 38(2-3), 105-112.

24. Iwueke, A. V., Nwodo, O. F. C., \& Okoli, C. O. (2006). Evaluation of the anti-inflammatory and analgesic activities of Vitex doniana leaves. African Journal of Biotechnology, 5(20), 1929.

25. Rasadah, M. A., Faredian, A., Wong, C. L., \& Ong, B. K. (2005). Anti-inflammatory activity of extracts and compound from Vitex negundo. Journal of Tropical Forest Science, 481487.

26. Kulkarni, R. R., Virkar, A. D., \& D'mello, P. (2008). Antioxidant and antiinflammatory activity of Vitex negundo. Indian journal of pharmaceutical sciences, 70(6), 838.

27. Mishra, S., Pani, S. R., \& Sahoo, S. (2014). Antinephrotoxic activity of some medicinal plants from tribal rich pockets of Odisha. Pharmacognosy research, 6(3), 210.

28. Herschman, H.R. (1996). Prostaglandin synthase-2. Biochemistry Biophysiology. Acta. 1299: 125-140.

29. Needleman, P., Isakson, P.C. (1997). The discovery and function of COX-2. Journal of. Rheumatology, 24: 6-8.

30. Apa I.A.V., Nwodo O.F.C., \& Okoli C.O. (2006). Evaluation of anti-inflammatory and analgesic activities of Vitex doniana leaves. African Journal of Biotechnology, 5(20):1929-1935. 